\title{
Effectiveness of Plantar Fascia-Specific Stretching Exercises in Plantar Fasciitis
} Plantar Fasiitis'te Plantar Fasya Spesifik Germe Egzersiz Tedavisinin Etkinliği

Devrim Özer, Alper Köksal*, Ali Öner**, Mehmet Akif Kaygusuz

Baltalimanı Osteopathic Training and Research Hospital, Clinic of Orthopedics and Traumatology, Istanbul, Turkey

*Merzifon State Hospital, Clinic of Orthopedics and Traumatology, Amasya, Turkey

**Mengücek Gazi Research and Training Hospital, Clinic of Orthopedics and Traumatology, Erzincan, Turkey

\section{Abstract}

Aim: Plantar fasciitis (PF) is a painful and disabling disease that affects the quality of life and daily activities of patients and it is the most common cause of heel pain in adults. In primary treatment, conservative treatment is suggested and different conservative options are described in the literature. In our study, we evaluated the efficacy of plantar fascia-specific stretching exercises in the treatment of PF

Methods: Twenty-nine feet - 21 patients with the mean age of 49.3 years were included in the study. The mean length of followup was 19.8 months and the mean length of exercise period was 4.94 months. Non-weight bearing plantar fascia-specific stretching exercise was done twice daily, for 10 times at each session. In addition to exercises, silicone heel pad and nonsteroidal antiinflammatory drugs (NSAID) were added. Visual analog scale (VAS) was used for pain evaluation.

Results: Full recovery detected in 15 feet in 10 patients (52\%) and a decrease in pain was seen in 10 feet in 8 patients (34\%). There was no response in 4 feet in 3 patients (14\%). There was statistically significant difference between pre-treatment and posttreatment visual analog scale scores $(p=0.0001)$.

Conclusion: Plantar fascia-specific stretching exercise is an effective treatment option in PF.

Keywords: Plantar fasciitis, plantar fascia-specific stretching exercise, painful heel treatment
Öz

Amaç: Plantar fasiitis (PF), hastaların hayat kalitesini etkileyen ağrılı ve engelleyici bir hastalıktır ve erişkin hasta grubunda en sık görülen topuk ağrısı sebebidir. Birincil tedavisinde konservatif tedavi önerilmekte olup literatürde değişik konservatif tedavi yöntemleri tanımlanmıştır. Çalışmamızda plantar fasya spesifik germe egzersizlerinin etkinliğini değerlendirdik.

Yöntemler: Yirmi bir hastanın 29 ayağı çalışmaya dahil edilmiştir. Ortalama yaş 49,3, ortalama takip süresi 19,8 ay ve ortalama egzersiz süresi 4,94 aydır. Plantar fasya spesifik germe egzersizleri günde 2 seans ve her seansta 10 kere yapıldı. Germe egzersizlerine ek olarak tedaviye silikon topukluk, non-steroid anti inflamatuvar ilaçlar (NSAID) eklendi. Görsel ağrı skalası [Visual analog scale (VAS)] ile ağrı ölçümü yapıldı.

Bulgular: On hastanın 15 ayağında (\%52) tam iyileşme saptandı. Sekiz hastanın 10 ayağında (\%34) ağrıda azalma saptandı ve 3 hastanın 4 ayağında (\%14) ise herhangi bir değişiklik saptanmadı. Tedavi öncesi ve sonrası VAS skorlarında istatistiksel olarak anlamlı fark bulundu $(p=0,0001)$.

Sonuç: Plantar fasya spesifik germe egzersizleri, plantar fasiitis tedavisinde etkili bir yöntemdir.

Anahtar Sözcükler: Plantar fasiitis, plantar fasya-spesifik germe egzersizi, ağrılı topuk tedavisi

Address for Correspondence/Yazışma Adresi: Devrim Özer

Baltalimanı Osteopathic Training and Research Hospital, Clinic of Orthopedics and Traumatology, The Medical Bulletin of Haseki Training and Research Hospital, istanbul, Turkey Phone: +90 5323468588 E-mail: drdevrimozer@gmail.com published by Galenos Publishing. 


\section{Introduction}

The plantar fascia is composed of fibrous connective tissue which is important for static structure of the longitudinal arch of the foot. The plantar fascia elongates with increased loads to act as a shock absorber, however, its ability to elongate is limited (1). Maximum elongation is about $4 \%$ of the structure and a force of approximately $1000 \mathrm{~N}$ is required to cause failure (2).

Plantar fasciitis (PF) is a disabling disease which negatively affects the quality of life and daily activities of patients. PF is the result of repetitive microtrauma at the origin of the medial tuberosity of the calcaneus (3). Thickness of the plantar fascia increases and also degeneration occurs $(4,5)$. PF is the most common cause of heel pain in adults. In the United States, more than 2 million people are affected every year $(6,7)$. In $90 \%$ of cases, symptoms relieve in 10 months (8), however, this long period is frustrating for both patients and clinicians (9).

Conservative treatment is the primary treatment choice in PF. Different conservative treatment methods are described, however, no single treatment has been proven to reduce heel pain (10). Plantar fascia-stretching exercises are one of the conservative treatment options suggested in the literature $(1,11-13)$.

In this study, the efficacy of plantar fascia-specific stretching exercises in conservative treatment of PF was evaluated.

\section{Methods}

The diagnosis of PF depends on the history and physical examination. In this study, the history of patients included a heel pain with the first step in the morning and which decreases by walking and increases again after standing for a long time. During physical examination, inferiormedial side of the heel was painful by palpation. Patients with bilateral heel pain were evaluated for systemic diseases; if a systemic disease was discovered, the patient was excluded from the study. The patients were evaluated for differential diagnosis of other inferior heel pain causing diseases, such as tarsal tunnel syndrome, L5-S1 radiculopathy, fat pad atrophy, calcaneal stress fracture, tumors or tumor-like lesions. Plain radiography was studied for all patients.

Between the years 2007 and 2008, patients with the complaint of heel pain were examined and 36 patients- 52 feet were diagnosed with PF. None of the patients had a history of previous surgery of the heel. All patients were asked to do the non-weight bearing plantar fascia-specific stretching exercises, twice a day, 10 times, for duration of 20 seconds each time (Figure 1,2). Silicone heel pad use during mobilization was suggested and non-steroidal anti-inflammatory drugs (NSAID) were prescribed, if there was no contraindication to NSAID use. The patients were informed that the exercise should be done regularly for 8 weeks which may be extended for a longer time and were called for follow-up visits every 2 months.

At the last follow-up visit, 15 patients-19 feet were excluded from the study due to non-compliance with the exercise program. During the last follow-up, single foot of 4 bilateral PF patients were left out by mistake. Therefore, those 4 feet were also excluded from the study. The study was done with 29 feet- 21 patients. Visual analogue scale (VAS) (0 to 10) was used for evaluation of pre-treatment and post-treatment pain complaints. Eighteen patients were female, 3 were male. The mean age was 49.3 years (24-72), the mean length of follow-up was 19.8 months (11-28 months), and the mean period of exercise was 4.94 months ( 0.25 to 24 months).

Informed consent was obtained from all patients, and the principles outlined in the Declaration of Helsinki were followed during the study.

\section{Statistical Analysis}

Statistical analysis was done using NCSS2007 software. For data assessment, definitive statistical methods (mean, standard deviation) were used and the Wilcoxon test for repetitive measures was studied.

\section{Results}

The pain resolved in 15 feet in 10 patients (52\%). A decrease in pain was detected in 10 feet in 8 patients (34\%) and there was no response to treatment in 4 feet in 3 patients (14\%) (Table 1).

Post-treatment VAS scores were statistically significantly lower than pre-treatment VAS scores in patients with PF who did plantar fascia-specific stretching exercises $(p=0.0001)$.

\section{Discussion}

Primary treatment of PF consists of conservative treatment methods. Surgical treatment options are considered when conservative methods are insufficient. In the literature, it has been recommended that before the decision for surgery is made, conservative treatment should continue for 6 to 12 months (14).

Conservative treatment options include shoe inserts (15), NSAIDs (16), night splints (17), stretching exercises $(12,13)$, extracorporeal shockwave therapy (ESWT) $(18,19)$, corticosteroid injection (20), botulinum toxin (botox) injection (21), taping (14), and casting (22).

Surgical intervention may be appropriate for patients who do not response to conservative treatment. However, recent studies have shown that surgery may associate with prolonged recovery time and persistent pain may not 


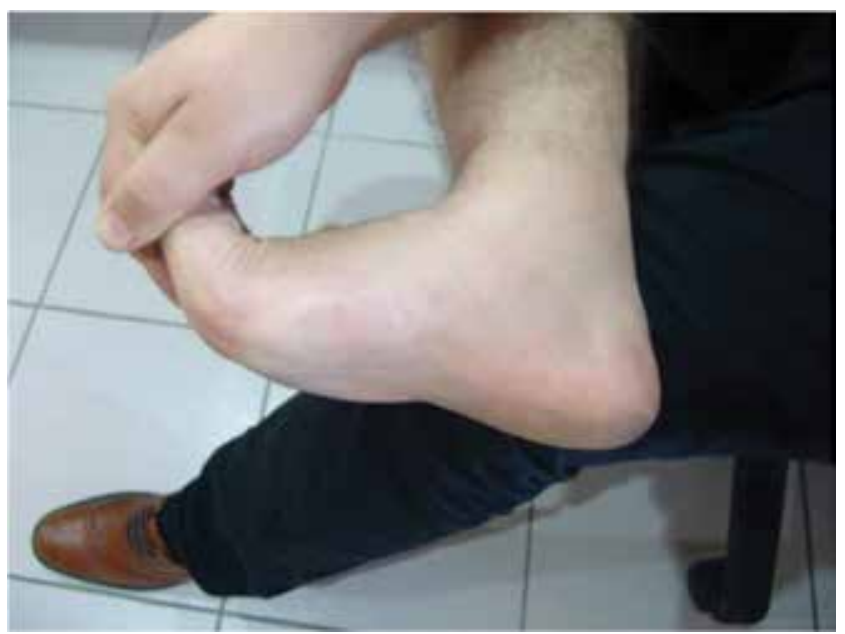

Figure 1. Plantar fascia - specific stretching exercise 1: Toes are holded at metatarsaophalangeal joint and pulled back for extension of the foot until stretching of the fascia is felt or tolerable pain is felt

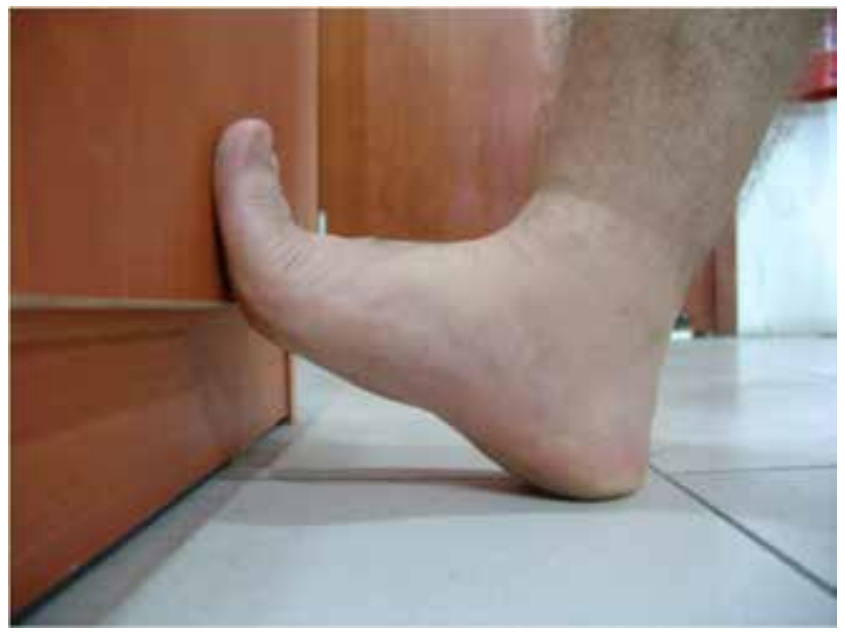

Figure 2. Plantar fascia - specific stretching exercise 2: Heel is hold on floor, toes until metatarsophalangeal joint stand on wall, pressure is done for stretching the plantar fasya

dissolve after surgery. Davies et al. (6) reported that less than $50 \%$ of patients with chronic heel pain were totally satisfied with the results of the surgical intervention. Therefore, we suggest surgical intervention to be the last resort for he treatment of PF.

ESWT is indicated in PF patients if PF lasts longer than 6 months and in those unresponsive to other conservative treatment modalities (11).

During the development phase of this study, a limited number of studies related to plantar fascia-stretching exercises were found in published literature. Two studies by DiGiovanni et al. (12) published in 2003 and 2006 were significant. While in the first study it was stated that plantar fascia-specific stretching exercises were more efficient than Achilles-stretching exercises, in the second study, they have showed that $58 \%$ of patients, who performed plantar fascia-specific stretching exercises, fully recovered, and $94 \%$ of patients benefited from stretching exercise treatment. They also pointed out that the length of the exercise period should be extended to 6 months; if no success after 6 months, then other treatment options might be considered (13).

Rompe et al. (23) compared stretching exercises and radial shock-wave therapy in PF patients. They concluded that a program of manual stretching exercises specific to the plantar fascia was superior to repetitive lowenergy radial shock wave therapy in the treatment of acute symptoms of proximal plantar fasciopathy, with a satisfaction rate of $65 \%$ and $29 \%$, respectively.

In their study, DiGiovanni et al. (12) investigated the preferred management of PF among orthopedic foot and angle surgeons. Eighty-four orthopaedic surgeons completed the survey. At the 4-month visit, 37 respondents (44\%) favored initiation of plantar fascia-specific stretching exercises; 62 respondents (74\%) preferred surgery or ESWT for patients with ongoing symptoms at 10 months as their next step in the management of PF (24).

Plantar fascia-specific stretching exercises are not efficient in all PF patients. We suppose it depends on different factors (body mass index, thickness of the plantar fascia, etc.) which should be further investigated. The lack of control group decreases the strength of our study.

In conclusion, plantar fascia-specific stretching exercise is an effective conservative treatment option and patients should be informed about the success rate and encouraged to perform regular exercise for PF treatment.

\section{Author Contributions}

Ethics Committee Approval: The study were approved by the Local Ethics Committee of Baltalimanı Osteopathic Training and Research Hospital, Informed Consent: Consent form was filled out by all participants, Concept: Devrim Özer, Design: Devrim Özer, Data Collection or Processing: Alper Köksal, Ali Öner, Devrim Özer, Analysis or Interpretation: Devrim Özer, Mehmet Akif Kaygusuz, Literature Search: Devrim Özer, Writing: Devrim Özer, Ali Öner, Peer-review: Internal peer-reviewed. Conflict of Interest: No conflict of interest was declared by the authors, Financial Disclosure: The authors declared that this study has received no financial support.

\section{References}

1. Brotzman SB. Inferior heel pain (plantar fasciitis), in Clinical Orthopaedic Rehabilitation. In: Brotzman SB, Wilk KE, editors. 2nd ed. Mosby Inc, St Lois, 2003. p.393.

2. Wright DG, Rennels DC. A study of the elastic properties of plantar fascia. J Bone Joint Surg Am 1964;46:482-92.

3. Roxas M. Plantar fasciitis: diagnosis and therapeutic considerations. Altern Med Rev 2005;10:83-93. 
4. Karabay N, Toros T, Hurel C. Ultrasonographic evaluation in plantar fasciitis. J Foot Ankle Surg 2007;46:442-6.

5. Kane $D$, Greaney $T$, Shanahan $M$, et al. The role of ultrasonography in the diagnosis and management of idiopathic plantar fasciitis. Rheumatology (Oxford) 2001;40:1002-8.

6. Davies MS, Weiss GA, Saxby TS. Plantar fasciitis: how successful is surgical intervention? Foot Ankle Int 1999;20:803-7.

7. Schepsis AA, Leach RE, Gorzyca J. Plantar fasciitis. Etiology, treatment, surgical results, and review of the literature. Clin Orthop Relat Res 1991:185-96.

8. Davis PF, Severud E, Baxter DE. Painful heel syndrome: results of nonoperative treatment. Foot Ankle Int 1994;15:531-5.

9. League AC. Current concepts review: plantar fasciitis. Foot Ankle Int 2008;29:358-66.

10. Healey K, Chen K. Plantar fasciitis: current diagnostic modalities and treatments. Clin Podiatr Med Surg 2010;27:369-80.

11. Lee TH, Maurus PB. "Plantar heel pain", in Surgery of the Foot and Ankle. In: Couglin MJ, Mann RA, Saltzman CL, editors. 8th ed. Mosby Inc, St Lois, 2007. p.689.

12. DiGiovanni BF, Nawoczenski DA, Lintal ME, et al. Tissuespecific plantar fascia-stretching exercise enhances outcomes in patients with chronic heel pain. A prospective, randomized study. J Bone Joint Surg Am 2003;85:1270-7.

13. Digiovanni BF, Nawoczenski DA, Malay DP, et al. Plantar fasciaspecific stretching exercise improves outcomes in patients with chronic plantar fasciitis. A prospective clinical trial with two-year follow-up. J Bone Joint Surg Am 2006;88:1775-81.

14. Toomey EP. Plantar heel pain. Foot Ankle Clin 2009;14:229-45.
15. Pfeffer G, Bacchetti P, Deland J, et al. Comparison of custom and prefabricated orthoses in the initial treatment of proximal plantar fasciitis. Foot Ankle Int 1999;20:214-21.

16. Donley BG, Moore T, Sferra J, Gozdanovic J, Smith R. The efficacy of oral nonsteroidal anti-inflammatory medication (NSAID) in the treatment of plantar fasciitis: a randomized, prospective, placebo-controlled study. Foot Ankle Int 2007;28:20-3.

17. Wapner KL, Sharkey PF. The use of night splints for treatment of recalcitrant plantar fasciitis. Foot Ankle 1991;12:135-7.

18. Haake $M$, Buch $M$, Schoellner $C$, et al. Extracorporeal shock wave therapy for plantar fasciitis: randomised controlled multicentre trial. BMJ 2003;327:75.

19. Ogden JA, Alvarez RG, Levitt RL, Johnson JE, Marlow ME. Electrohydraulic high-energy shock-wave treatment for chronic plantar fasciitis. J Bone Joint Surg Am 2004;86:2216-28.

20. Genc H, Saracoglu M, Nacir B, Erdem HR, Kacar M. Long-term ultrasonographic follow-up of plantar fasciitis patients treated with steroid injection. Joint Bone Spine 2005;72:61-5.

21. Babcock MS, Foster $L$, Pasquina P, Jabbari $B$. Treatment of pain attributed to plantar fasciitis with botulinum toxin a: a shortterm, randomized, placebo-controlled, double-blind study. Am J Phys Med Rehabil 2005;84:649-54.

22. Tisdel CL, Harper MC. Chronic plantar heel pain: treatment with a short leg walking cast. Foot Ankle Int 1996;17:41-2.

23. Rompe JD, Cacchio A, Weil L Jr, et al. Plantar fascia-specific stretching versus radial shock-wave therapy as initial treatment of plantar fasciopathy. J Bone Joint Surg Am 2010;92:2514-22.

24. DiGiovanni BF, Moore AM, Zlotnicki JP, Pinney SJ. Preferred management of recalcitrant plantar fasciitis among orthopaedic foot and ankle surgeons. Foot Ankle Int 2012;33:507-12. 